\title{
INVESTIGATING STUDENT SATISFACTION IN ONLINE LEARNING: THE ROLE OF STUDENT INTERACTION AND ENGAGEMENT IN DISTANCE LEARNING UNIVERSITY
}

\author{
Moh. MUZAMMIL \\ ORCID: 0000-0002-7928-0396 \\ Faculty of Economics \\ Universitas Terbuka \\ Tangerang Selatan, INDONESIA \\ Adrian SUTAWIJAYA \\ ORCID: 0000-0002-1600-2743 \\ Faculty of Economics \\ Universitas Terbuka \\ Tangerang Selatan, INDONESIA \\ Dr. Meirani HARSASI \\ ORCID: 0000-0003-1910-0290 \\ Faculty of Economics \\ Universitas Terbuka \\ Tangerang Selatan, INDONESIA
}

Received: 05/09/2019 Accepted: 12/06/2020

\begin{abstract}
This study aimed to analyze student satisfaction and engagement effect in online learning which are influenced by student interaction. We use the concept of interaction which is divided into three types of interactions, namely student interactions with other students, student interactions with tutors/teachers, and student interactions with content. We conducted this research in an open and distance learning university in Indonesia. To answer the research goals, we applied a quantitative research approach utilizing structural equation modelling to verify our proposed hypotheses. To gain the data, we exploit an online survey through a questionnaire and the data were being collected randomly. The population of this study was all students in Faculty of Economics who registered in online learning at the first semester of 2018 that reach as many as 124,041 students. We attached the questionnaires in all online classes and 4,305 of them were completed and could be used for statistical analysis. We proposed four hypotheses and based on the result of structural modelling, we verified that all the hypotheses were supported. The statistical analysis has found that interaction among students, interaction between students and teacher, and interaction between students and content have positive impact on student engagement. The results also showed that student engagement has positive impact on student satisfaction. We discuss the practical implication and suggestion for future research in the results and discussion section.
\end{abstract}

Keywords: Interaction, online learning, student engagement, student satisfaction

\section{INTRODUCTION}

Many studies in online learning area have widely expressed the importance of student satisfaction as it associates to student success in learning. Several previous empirical studies have verified the existence of various variables that influence student satisfaction. Furthermore, interaction tends to become an important topic in many researches that affect student satisfaction in online learning (Mandernach, 2005). This 
interaction can occur among students, between students and their teachers/tutors, and between students and course content. Likewise, student engagement also plays an important role for student success in an online environment. However, we found that there is limited studies investigating the influence of student engagement on student satisfaction. The importance of student engagement in online learning has confirmed due the thought that it can be demonstrated through cognitive development of student and their ability to construct knowledge in order to drive their successful in learning (Banna et al., 2015). However, it is contrary to the fact that student tends to have fewer opportunities to be engaged with the institution in online environment (Martin \& Bolliger, 2018). According to this condition, creating student engagement becomes an important point for managing online learning to attain student satisfaction. Furthermore, it is also important to explore how engagement is constructed by interaction in online learning.

Student satisfaction becomes an important topic in Open and Distance Learning (ODL) practice, including in our university. In recent years, we have experienced a decline in the number of our students as stated by Sembiring (2017). Since 2011 until 2015, the number of our students are 446,326; 415,030; 353,193; 333,501; and 309,508 students. We estimate, that there will be a decline in the number of students in next years. However, in our strategic plan, we already established that the number of our students is expected not less than 250,000 students to sustain our existence (Universitas Terbuka, 2014). Realizing how crucial this issue for us, it is reasonable to explore how to attain student satisfaction in our learning activities.

The purpose of present study was to investigate the influence of student engagement on student satisfaction, where engagement is determined by interaction. We emphasize on student satisfaction in learning process due the condition, that nowadays, we offer online learning for all subjects. Therefore, the main purpose of present research are (1) to investigate the influence of interaction on student engagement, and (2) to investigate the influence of student engagement on student satisfaction. We analyzed the interaction in online learning based on the interaction among students, interaction between student and tutor, and interaction between student and course content.

\section{LITERATURE REVIEW}

In a various literature and previous research, engagement and interaction are closely associated in online learning. The importance of student engagement in online learning has stated by Martin \& Bolliger (2018). Anderson (2003) has found that interaction can create student engagement, and furthermore, interaction is also found as an essential topic related to student success in online learning. Student success become critical in online environment since online environment encourage students to depend mostly on their ability to learn. Verneil \& Berge (2000) has shown that student success in online learning mostly supported by their activity during learning process. Blasco-Arcas et al. (2013) stated that there are two factors that are directly associated to active learning, those are interactions and engagement. Wang \& Baker (2015) stated that student engagement is student effort to get involve in learning processes of a specific course. It is also become one of important variable in conducting online learning effectively (Dixson, 2010).

In an online environment, there are three types of interaction in engagement as proposed by Bernard et al. (2009), those are interaction between students, interaction of student to instructor, and interaction of student to content. Lear et al. (2010) who has proven that those types of interaction can help students to be more active and more engaged in their learning support this concept. Being consistent with that opinion, Martin \& Bolliger (2018) also confirmed that engagement is critical to student learning and student satisfaction in their learning process, therefore student engagement can increase student satisfaction.

\section{CONCEPTUAL FRAMEWORK AND HYPOTHESES}

We propose the topic of this study is important in the context of distance education system that student satisfaction in online learning becomes an important aspect. The underlying reason is that the success of students in online learning is greatly influenced by student satisfaction, thus will lead them to complete their studies. In our university, as it is implementing open and distance education, we have a policy to give students flexibility during their learning process, including flexibility for students to register in the next semester. This system encourage us to focus on the effort to satisfy our students so that we can keep them 
registered untill they graduate. Considering the goal of our organization and also several related literature and previous researches, we proposed conceptual framework as presented in Figure 1.

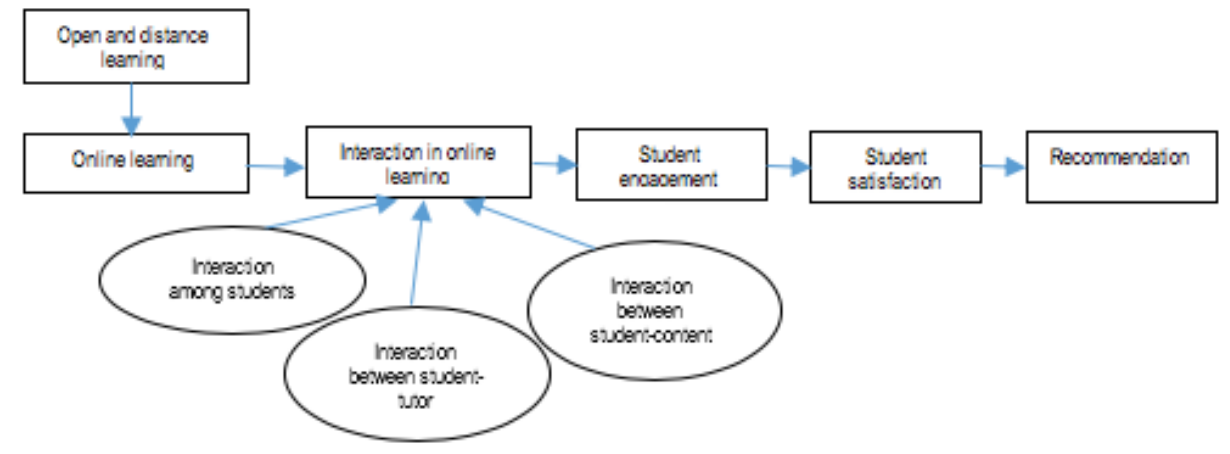

Figure 1. Conceptual framework

According to related literature and previous research, we propose four hypotheses as follows:

H1: Interaction of student to student has a positive effect on student engagement

$\mathrm{H} 2$ : Interaction of students to tutor/teacher has a positive effect on student engagement

H3: Interaction of students to course content has a positive effect on student engagement

H4: Student engagement has a positive effect on student satisfaction

\section{METHODOLOGY}

\section{Research Instruments}

As mentioned previously, this study aimed to investigate student satisfaction in online learning through student engagement and interaction. Thus, there were five variables that we employed in the present study. The variables consist of three exogenous variables, those are interaction of students to other students, interaction of students to tutor, and interaction of student to course content; and two endogenous variables, those are student engagement and student satisfaction. As we design this study as confirmatory study, we developed the variables and hypotheses based on previous researches. Thus, the questionnaire was also developed based on previous researches with some adjustments to our condition. Table 1 shows references of each research variable. A 5-point Likert scale was utilized to measure respondent's response on each question with the range from 1 (strongly disagree) until 5 (strongly agree).

Table 1. References of the Research Variables

\begin{tabular}{ll}
\hline \multicolumn{1}{c}{ Variable } & References \\
\hline Interaction students and students & Johnson et al. (2000) \\
Interaction student and tutor & Peltier et al. (2003), Johnson et al. (2000) \\
Interaction student and course content & Peltier et al. (2003), Bernard et al. (2009) \\
Student engagement & Gray \& DiLoreto (2016) \\
Student satisfaction & Gray \& DiLoreto (2016) \\
\hline
\end{tabular}




\section{Participants}

This research is conducted based on the importance of online learning in ODL institution. More specifically, it focused on the online learning of the Faculty of Economics. To answer the research objectives, we need primary data in the form of opinions from students who take online learning. Therefore, the population of this study was all students in Faculty of Economics who registered in online learning at the first semester of 2018 that reach as many as 124,041 students. Simple random sampling was chosen as the most appropriate sampling technique to obtain data from the participants. As many as 4,305 students responded to the survey.

\section{Data Collection}

After developing the instrument, we sent the instrument in the form of a questionnaire to all online tutorial classes. The instrument was created in the form of an online questionnaire that made it easy for students to answer and automatically sent back the answers to us. The consideration of selecting an online questionnaire is that it made us easier to collect the answers as they are recapitulated directly by the system.

\section{Data Analysis}

To verify the research hypotheses, we applied structural equation modelling. However, before testing the hypotheses, we tested the research variables and indicators. The reliability of research variable was tested using Cronbach's Alpha while the validity test of indicator was performed using confirmatory factor analysis.

\section{FINDINGS}

The collected data was then analyzed to test the proposed hypotheses. However, as mentioned earlier, before conducting a hypothesis test to determine the effect among variables, we must ensure that all indicators have met validity requirements and all variables have met reliability requirements as well. Having this reason, a validity test and a reliability test are performed first. These tests are needed to ensure that indicators and variables in this study are feasible to serve as input to test the hypotheses. The reliability test was carried out using Cronbach's Alpha with criteria a variable which has reliability estimate of .7 or higher suggests as a variable with good reliability (Hair et al., 2014). After conducting a reliability test, we then conducted a validity test using confirmatory factor analysis with standardized loading estimate of each indicator should be .5 or higher (Hair et al., 2014). After the reliability and validity tests have been carried out, the final step was to conduct a structural model test to verify the effect among variables.

The reliability test results showed that all variables were statistically confirmed to have the requirements as reliable variables as verified by the results of the Cronbach's Alpha based on standardizes items are higher than .6 as presented in Table 2 .

Table 2. Reliability test

\begin{tabular}{lcl}
\hline \multicolumn{1}{c}{ Variable } & $\begin{array}{c}\text { Cronbach's Alpha based on } \\
\text { standardized item }\end{array}$ & Remark \\
\hline Interaction among students & .923 & Reliable \\
Interaction between student-tutor & .928 & Reliable \\
Interaction between student-content & .878 & Reliable \\
Student engagement & .876 & Reliable \\
Student satisfaction & .930 & Reliable \\
\hline
\end{tabular}

The next step was to test the validity of indicators through confirmatory factor analysis and also the influence of variables as presented in Figure 2. The figure shows that all indicators in each variable are valid as verified by all the estimated values of the indicators are higher than .5 . 


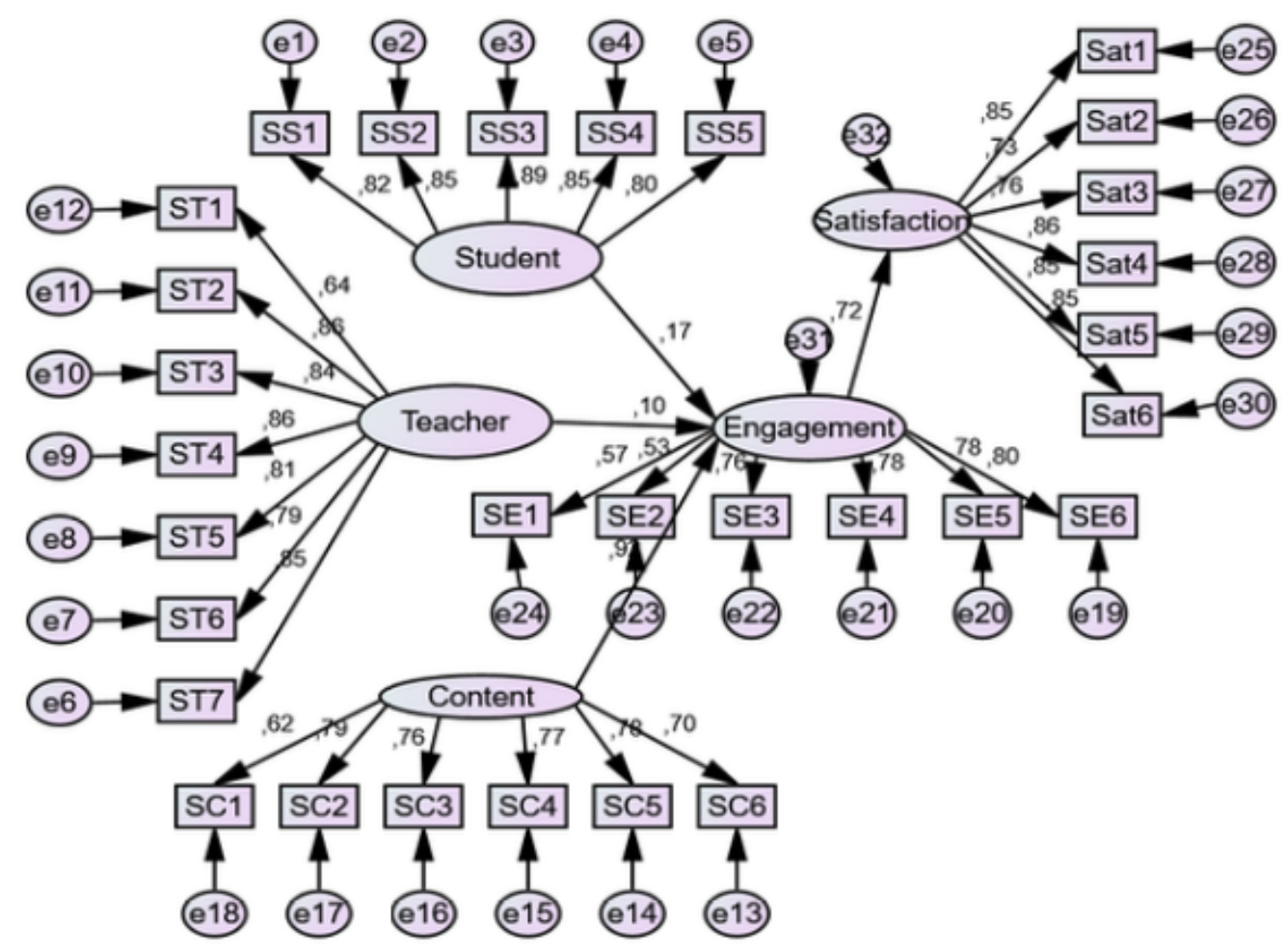

Figure 2. Structural Modelling

The result of validity test is presented in Table 3 .

Table 3. Validity result

\begin{tabular}{lccc}
\hline \multicolumn{1}{c}{ Variable } & Indicator & Estimate & Remark \\
\hline Interaction among & SS1 & .82 & Valid \\
students & SS2 & .85 & Valid \\
& SS3 & .89 & Valid \\
& SS4 & .85 & Valid \\
Interaction between & SS5 & .80 & Valid \\
student- tutor/teacher & ST1 & .64 & Valid \\
& ST2 & .86 & Valid \\
& ST3 & .84 & Valid \\
Interaction between & ST4 & .86 & Valid \\
student-content & ST5 & .81 & Valid \\
& ST6 & .79 & Valid \\
& ST7 & .85 & Valid \\
Student engagement & SC1 & .62 & Valid \\
& SC2 & .79 & Valid \\
SC3 & SC4 & .76 & Valid \\
Student satisfaction & SC5 & .77 & Valid \\
& SC6 & .78 & Valid \\
& SE1 & .70 & Valid \\
& SE2 & .57 & Valid \\
SE3 & SE4 & .53 & Valid \\
& SE5 & .76 & Valid \\
\end{tabular}


After conducting the validity test, the next step was to test the structural model. First, we tested the goodnessof-fit models to verify the accuracy of the model. According to our hypotheses, the result indicated that our model is acceptable as model that meet the criteria of goodness-of-fit model. The result showed that CFI, RMSEA, and NFI of the model are in the range of recommended values suggesting the model is quite fit. The results are presented in Table 4. After the model has proven as a fit model, the next step is to test the influence among variables. Table 5 shows the standardized parameter estimates and $\mathrm{p}$ values for hypotheses 1 - hypotheses 4 . The finding suggested that all the interaction proposes are good determinants for engagement. Another finding was that student engagement has proven serve as a good determinant of student satisfaction. All standardized regression of variables were significant at $\mathrm{p}=0.000$ and $\mathrm{a}=0.01$.

Table 4. Fit indices

\begin{tabular}{llll}
\hline \multicolumn{1}{c}{ Fit Measures } & Study & \multicolumn{1}{c}{ Cut-off Value } & Remark \\
\hline \multirow{2}{*}{ CFI } & & $\mathrm{CFI} \geq 0.90=$ good fit & marginal fit \\
& 0.808 & $0.80 \leq \mathrm{CFI}<0.90=$ marginal fit & \\
RMSEA & $<0.80=$ poor fit & marginal fit \\
& 0.042 & $\mathrm{RMSEA} \leq 0.08$ & \\
$\mathrm{NFI}$ & $\mathrm{p}<0.05$ & marginal fit \\
& & $\mathrm{NFI} \geq 0.90=$ good fit \\
\hline
\end{tabular}

Table 5. Hypotheses testing

\begin{tabular}{lcc}
\hline \multicolumn{1}{c}{ Description } & Standardized Estimate & p value \\
\hline Interaction among students $\rightarrow$ Student engagement & .169 & 0.000 \\
interaction student-tutor $\rightarrow$ Student engagement & .095 & 0.000 \\
interaction student-content $\rightarrow$ Student engagement & .919 & 0.000 \\
Student engagement $\rightarrow$ Student satisfaction & .722 & 0.000 \\
\hline
\end{tabular}

The results verified that when students become more active in online learning through interaction among students, interaction with tutors, and interaction with content, it will strengthen their engagement. This relationship will ultimately lead to student satisfaction as well. Another result also shows that interaction between student and tutor has the lowest estimate value compared to other interactions, which indicated that this variable as the weakness one.

\section{DISCUSSION}

The results of this study reinforce the results of previous studies regarding the importance of interaction and engagement in online learning to achieve student satisfaction. Some significant contribution on literature regarding online learning are as follows. First, the model has confirmed that interaction in online learning is important in creating student engagement. Second, the study also confirmed that student engagement is also important determinants in creating student satisfaction. Student engagement aims to provide positive learning experiences for students, including active learning, such as discussion in collaborative work groups, conducting presentations and discussions, sharing resources, doing assignments, and integrating case studies with reflection (Martin \& Bolliger, 2018). Banna, et al. (2015) also stated that student engagement is a solution to various problems in online learning, such as school dropouts, retention, and student graduation rates. The results of present study support previous research by Gray and DiLoreto (2016) which confirmed that student engagement mediates the relationship of learner interaction and student satisfaction. This result also supports previous research by Eom (2009). The research was focus on the importance of interaction in online environment; that interaction in online courses has recognized as the most important structure in determining the quality of web-based course. 
This research was conducted in the open education institution that implements distance learning. In the distance learning environment is somewhat different from the face-to-face environment. When learning is conducted online, students have limitations to interact with other parties in learning, such as other students, tutors, or content. We design our e-learning as asynchronous learning which means that communication can only be done in one direction at the same time. When students have questions related to the subject being studied, students can ask other parties such as tutors or peers, but these questions cannot be answered immediately. The system will save the question and other students or tutors can answer it when they log into the system. Such system obviously has weaknesses when interactions cannot be carried out directly. Therefore, the step we can take in this matter is to encourage tutors to always be active in online learning so that it makes easier for students to interact.

In an online learning environment, easiness of interaction is the key to student learning success. Therefore, system reliability and tutor's speed response become important aspects in this regard. Unfortunately, the result of this study indicates that the interaction between students and tutors has the lowest estimate value. This result is contrary to previous research by Gray and DiLoreto (2016) and Kuo, et al. (2013). We investigated various possibilities that caused it to be happened by reviewing to the questionnaire. The items that measure interaction between student-tutor refer to tutor's activity in encouraging student to be active during learning process. The low estimate value might be caused by two reason. First, respondents might think that the role of tutors in this matter is not significant for them. Since the respondents have become accustomed to study independently via online, it is obvious that they can learn by themselves. Alternatively, second, respondents might think that tutors are not encourage them in online learning. These results require further research so that definitive causes can be determined so that appropriate practical implications can be implemented.

\section{CONCLUSION}

This study aims to analyze the effect of interaction in online learning on student engagement and the effect of student engagement on student satisfaction. The results showed that all interaction patterns, namely interactions between students, interactions between students and tutors, and student interactions with content have proven to have a positive effect on student engagement. Likewise, student engagement also has proven to have a positive effect on student satisfaction. The results of this study are expected to serve as evidence of improvements in the implementation of online learning at our university. The key result that interaction is an important variable to achieve student satisfaction, we must strive to improve our online learning system, so that students can more easily interact in online learning. However, this research has several weaknesses, among others we cannot examine in more depth precisely how interactions can strengthen student engagement. We also expect that future studies can continue to refine this research by analyzing more deeply, for example by qualitative research, which interaction factors can strengthen student engagement.

\section{BIODATA and CONTACT ADDRESSES of AUTHORS}

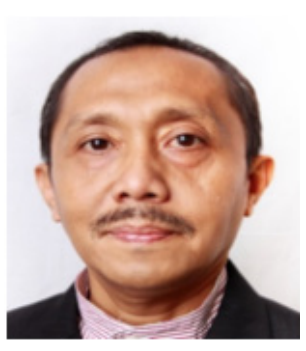

Moh. MUZAMMIL is a senior lecturer in Faculty of Economics, Universitas Terbuka, Indonesia. His majors are Marketing and Strategic Management. While serving as a lecturer in Department of Business/Management, he was once Head of Department of Management and Dean of Faculty of Economics. Now, he is a Vice Rector for Finance and General Affairs for Universitas Terbuka. During his 33 years working at Universitas Terbuka, he also teaches marketing, strategic management, and human resources management. His field of researches are distance education and e-learning. He has published several articles in both international and national journals.

Moh. MUZAMMIL

Department of Management, Faculty of Economics

Universitas Terbuka, 15418, Tangerang Selatan, Indonesia

Phone: +62 81519485375

E-mail: muzamil@ecampus.ut.ac.id 


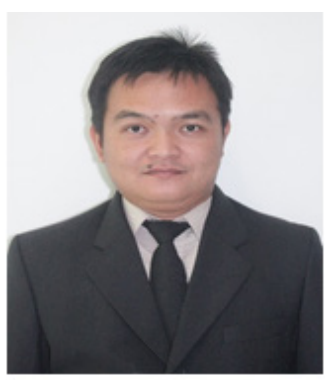

Adrian SUTAWIJAYA is a lecturer in Faculty of Economics, Universitas Terbuka, Indonesia. He gained his Master Degree in Economic Development from Universitas Diponegoro, Indonesia. While serving as a lecturer in Department of Economics Development, he is also the head of Procurement Division of Universitas Terbuka. During his working experience at Universitas Terbuka, he has taught some subjects related to economics such as micro-economics, macro-economics, and income distribution. His interest are not only in the area of economics, but also in the area of education such as distance education and e-learning. During his career as a lecturer, he has published 2 articles in International journals and 8 articles in national journals.

\section{Adrian SUTAWIJAYA}

Department of Economic Development, Faculty of Economics

Universitas Terbuka, 15418, Tangerang Selatan, Indonesia

Phone: +62 81310328272

E-mail: adrian@ecampus.ut.ac.idadrian@ecampus.ut.ac.id

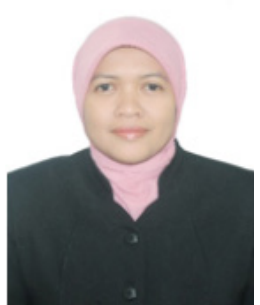

Dr. Meirani HARSASI is an associate professor in Faculty of Economics, Universitas Terbuka, Indonesia. Some of her relevant researches are in the area of management including organization, human resource management, and strategic management. To support her profession in higher education, she also conducted research in the area of education, such as distance education and online learning. Through her career as a lecturer, she has published her work in 4 international indexed journals, 5 international journals, 2 national journals, and 5 international proceedings.

Meirani HARSASI

Department of Management, Faculty of Economics

Universitas Terbuka, 15418, Tangerang Selatan, Indonesia

Phone: +62 81519485375

E-mail: rani@ut.ac.id rani@ecampus.ut.ac.id

\section{REFERENCES}

Anderson, T. (2003). Modes of interaction in distance education: Recent developments and research questions. In M. G. Moore \& W. G. Anderson (Eds.), Handbook of distance education (pp. 129144). Mahwah, NJ : Lawrence Erlbaum Associates Inc.

Banna, J., Lin, M-F. G., Stewart, M., \& Fialkowski, M. K. (2015). Interaction matters: Strategies to promote engaged learning in an online introductory nutrition course. Journal of Online Learning and Teaching, 11(2), 249-261.

Bernard, R. M., Abrami, P. C., Borokhovski, E., Wade, C. A., Tamim, R. M., Surkes, M. A., \& Bethel, E. C. (2009). A meta-analysis of three types of interaction treatments in distance education. Review of Educational research, 79(3), 1243-1289.

Blasco-Arcas, L., Buil, I., Hernandez-Ortega, B., \& Sese, F.J. (2013). Using clickers in class. The role of interactivity, active collaborative learning and engagement in learning performance. Computers \& Education, 62, 102-110.

Dixson, M. D. (2010). Creating effective student engagement in online courses: What do students find engaging? Journal of the Scholarship of Teaching and Learning, 10(2), 1-13.

Eom, S. (2009). Effects of interaction on students' perceived learning satisfaction in university online education: An empirical investigation. International Journal of Global Management Studies, 1(2), 60-74. 
Fredricks, J. A., Filsecker, M., \& Lawson, M. A. (2016). Student engagement, context, and adjustment: Addressing definitional, measurement, and methodological issues. Learning and Instruction, 43, $1-4$.

Gray, J. A., \& DiLoreto, M. (2016). The effects of student engagement, student satisfaction, and perceived learning in online learning environments. International Journal of Educational Leadership Preparation, 11(1), 98-119.

Hair, J.F., Black, W.C., Babin, B.J., \& Anderson, R.E. (2014). Multivariate Data Analysis. $7^{\text {th }}$ edition. Harlow: Pearson Education Limited.

Herbert, M. (2006). Staying the Course: A Study in Online Student Satisfaction and Retention. Online Journal of Distance Learning Administration, 9(4), 300-317.

Johnson, S.D., Aragon, S.R., Shaik, N. \& Palma-Rivas, N. (2000). Comparative analysis of learner satisfaction and learning outcomes in online and face-to-face learning environments. Journal of Interactive Learning Research, 11(1), 29-49.

Kuo, Y., Walker, A. E., Belland, B. R., \& Schroder, K. E. E. (2013). A predictive study of student satisfaction in online education programs. The International Review of Research in Open and Distance Learning, 14(1), 16-39.

Lear, J. L., Ansorge, C., \& Steckelberg, A. (2010). Interactivity/community process model for the online education environment. Journal of Online Learning and Teaching, 6(1), 71-77.

Mandernach, B. J. (2005). A faculty evaluation model for online instructors: Mentoring and evaluation in the online classroom. Online Journal of Distance Learning Administration, 8(3), 1-10.

Martin, F. \& Bolliger, D.U. (2018). Engagement matters: Student perceptions on the importance of engagement strategies in the online learning environment. Online Learning, 22(1), $205-222$.

Peltier, J.W., Drago, W., \& Schibrowsky, J.A. (2003). Virtual communities and the assessment of online marketing education. Journal of Marketing Education, 25 (3), 260-276.

Sekaran, U., \& Bougie, R. (2013). Research Methids for Business. A Skill-Building Approach. $\sigma^{\text {th }}$ edition. Chichester: John Wiley \& Sons, Ltd.

Sembiring, M.G. (2017). Exploratory study of academic excellence associated with persistence in ODL setting. Asian Association of Open University Journal, 12(2), 125-136.

Universitas Terbuka. (2014). Strategic and Operational Planning of Universitas Terbuka 2014-2021. Jakarta: Universitas Terbuka

Verneil, M., \& Berge, Z. (2000). Going online: Guidelines for faculty in higher education. Educational Technology Review, 6(3), 13-18.

Wang, Y., Baker, R. (2015). Content or platform: why do students complete MOOCs?. Journal of Online Learning and Teaching, 11(1), 17-30. 